\title{
Ten commonly asked questions about Covid-19 and lessons learned from Thailand
}

\author{
Pramon Viwattanakulvanid \\ College of Public Health Sciences, Chulalongkorn University, \\ Bangkok, Thailand
}

\begin{abstract}
Purpose - As the world faces a new health crisis threatening people with the spread of Covid-19, this study aims to summarize the key information of Covid-19 related to disease characteristics, diagnosis, treatment and prevention along with the lessons learned from Thailand.

Design/methodology/approach - The narrative review was synthesized from various sources such as the World Health Organization; Centers for Disease Control and Prevention; Ministry of Public Health and other related news; articles in ScienceDirect, PubMed, Google Scholar; and the author's perspective regarding the lessons learned from Thailand with keywords of "Covid-19" and "Coronavirus" from January to August 2020. Google Trends was used to set common questions.

Findings - Covid-19 is the seventh family of coronaviruses that cause various symptoms related to respiratory systems. The disease can be treated through general and symptomatic treatment, by using antiviral drugs. As of July 2020, there are four potential vaccine candidates ChAdOx1 nCoV-19, mRNA-1273, Ad5-nCOV and BNT162b1. The recommendations for Covid-19 prevention are physical distancing, face masks, eye protection and hand washing. Thailand is now considered as low-risk for Covid-19 possibly because of (1) soft policy by government actions, (2) village health volunteers, (3) integration of technology and (4) fact-based communications.

Originality/value - This study summarized the key points about Covid-19, clarified some misunderstandings and shared strategic actions from Thailand, which can be adapted according to the different capacities and situations in other countries.
\end{abstract}

Keywords Coronavirus, Covid-19, Pandemic, Respiratory syndrome, Thailand

Paper type Review

\section{What is Covid-19?}

Covid-19 is the official name of a new disease related to severe acute respiratory syndrome coronavirus 2 (SARS-CoV-2) given by the World Health Organization (WHO) on February 11, 2020. This virus is the seventh member of the coronavirus family, as shown in Table 1 . The six members of the family of coronaviruses are 229E, OC43, NL63 and HKU1, which typically cause common cold symptoms in patients with low immunity. The remaining members of the coronavirus family are severe acute respiratory syndrome coronavirus (SARS-CoV) and Middle East respiratory syndrome coronavirus (MERS-CoV), which are zoonotic viruses transmitted to humans through close contact with infected animals. Coronaviruses are enveloped RNA viruses in different species such as humans, birds and other mammals, which cause respiratory, enteric, hepatic and neurological illness [1]. In a recent study, Covid-19

(C) Pramon Viwattanakulvanid. Published in Journal of Health Research. Published by Emerald Publishing Limited. This article is published under the Creative Commons Attribution (CC BY 4.0) licence. Anyone may reproduce, distribute, translate and create derivative works of this article (for both commercial and non-commercial purposes), subject to full attribution to the original publication and authors. The full terms of this licence may be seen at http://creativecommons.org/licences/by/4.0/ legalcode

The author would like to thank all scientists and clinicians working together on Covid-19 in order to save lives around the world.

Conflict of interest. None.
Received 27 August 2020 Revised 3 November 2020 13 November 2020 Accepted 23 November 2020 


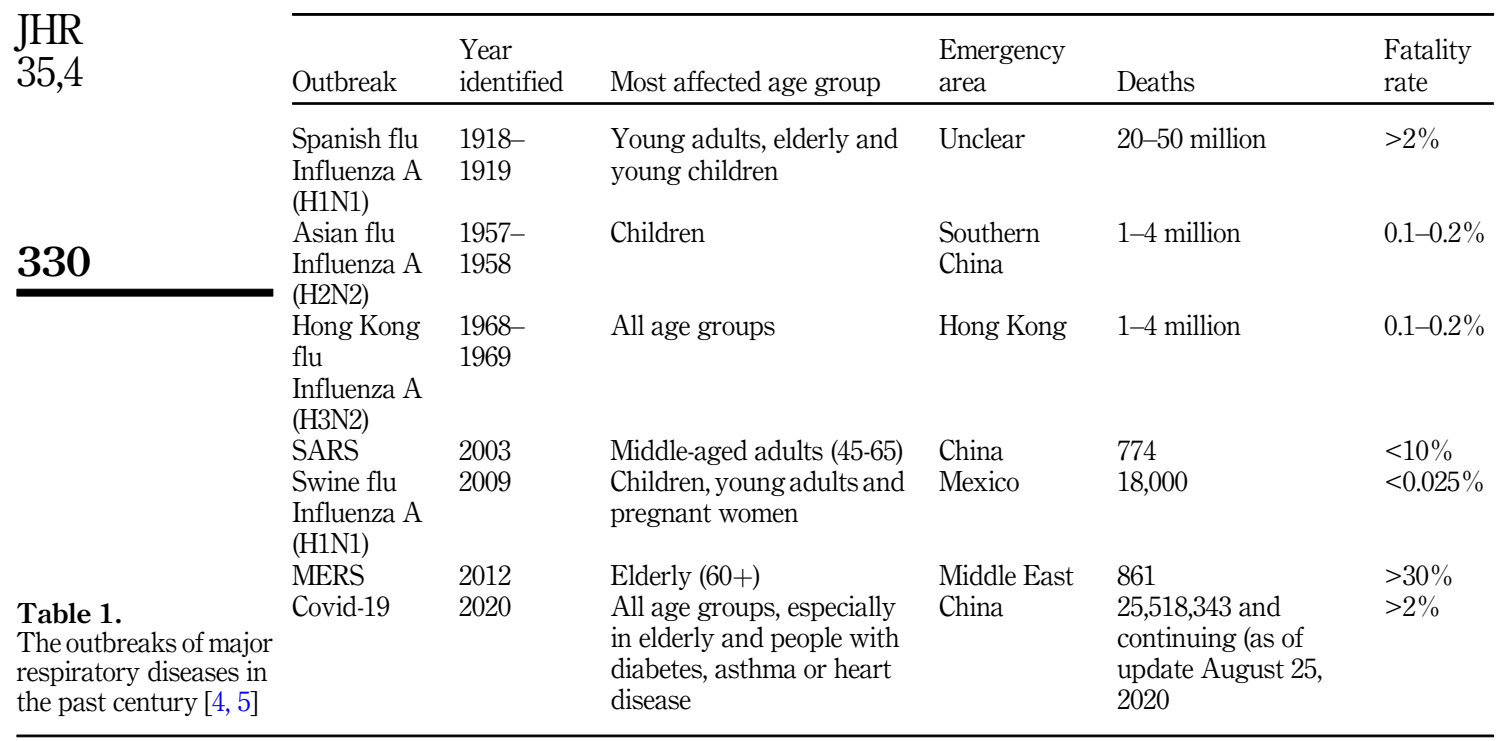

showed two major types of the virus as L type (70\%; more prevalent, more aggressive and spread more quickly) and $\mathrm{S}$ type (30\%; less aggressive and evolution older) [2, 3].

\section{How was Covid-19 originated?}

In December 2019, there was a group of acute respiratory illness patients with unknown causes, now known as Covid-19, that occurred in a seafood wholesale market in Wuhan, Hubei Province, China. Then, the outbreak of Covid-19 spread rapidly from Wuhan to other areas and different countries. At present (as of August 2020), the WHO reported that the confirmed Covid-19 cases spread to all regions such as Americans, Europe, South-East Asia, Eastern Mediterranean, Africa and Western Pacific [5]. The origin of Covid-19 was still inspected, and the current evidence identified that the spread to humans potentially occurred through transmission from wild animals sold in the Huanan Seafood Wholesale Market [6].

\section{What are the clinical features of patients with Covid-19?}

On January 2, 2020, the study [7] reported 41 patients (age between 41 to 61 years old) in Wuhan, China, who were admitted to the hospital and had common symptoms at the onset of illness as (1) fever (98\%), (2) cough (76\%), (3) myalgia or fatigue (44\%), (4) sputum production (28\%), (5) headache (8\%), (6) hemoptysis (5\%) and (7) diarrhea (3\%). Also, all patients had pneumonia with abnormal findings on a chest computed tomography (CT). According to the retrospective study [8], 99 patients ranging in age from 21 to 82 years old, recruited from January 1 to January 20, 2020, with Covid-19 had clinical manifestations of (1) fever (83\%), (2) cough $(82 \%)$, (3) shortness of breath (31\%), (4) muscle ache $(11 \%),(5)$ confusion $(9 \%),(6)$ headache $(8 \%)$, (7) sore throat $(5 \%),(8)$ rhinorrhea $(4 \%),(9)$ chest pain $(2 \%)$ and $(10)$ diarrhea $(2 \%)$. Additionally, the study [6] with 138 hospitalized patients with Covid-19 from January 1 to January 28, 2020 reported the signs and symptoms to be (1) fever (98.6\%), (2) fatigue $(69.6 \%),(3)$ dry cough $(59.4 \%),(4)$ anorexia $(39.9 \%)$, (5) myalgia $(34.8 \%),(6)$ dyspnea $(31.2 \%)$, (7) expectoration $(26.8 \%)$, (8) pharyngalgia $(17.4 \%)$, (9) diarrhea $(10.1 \%)$ and $(10)$ nausea 
(10.1\%). In summary, the common Covid-19 symptoms include fever, dry cough, fatigue and shortness of breath and tends to be severe in the elderly and people with health conditions such as diabetes, asthma or heart disease [9].

According to the clinical manifestations, Covid-19 symptoms can be grouped based on the severity of illness as follows [10].

\subsection{Asymptomatic or pre-symptomatic infection}

Individuals who test positive for SARS-CoV-2 by virologic testing using a molecular diagnostic (e.g. polymerase chain reaction - PCR) or an antigen test, but the absence of clinical signs and symptoms with normal chest or CT scan.

\subsection{Mild illness}

Individuals who have any of the various signs and symptoms of Covid-19 (e.g. fever, chills, muscle pain, runny nose, cough, sore throat, headache and loss of taste or smell, nausea, vomiting, abdominal pain and diarrheas) and normal pulmonary clinical exam without pneumonia or breathing difficulties and dyspnea.

\subsection{Moderate illness}

Individuals who have evidence of lower respiratory tract disease by clinical exam or imaging with chest CT scan will show typically pulmonary lesions and saturation of oxygen $\left(\mathrm{SaO}_{2}\right) \geq 94 \%$ on room air at sea level.

\subsection{Severe illness}

Individuals whose clinical symptoms deteriorate and usually occur in a week with the development of dyspnea and hypoxemia, have respiratory frequency $>30$ breaths per minute, blood oxygen saturation $\left(\mathrm{SaO}_{2}\right)<94 \%$ on room air at sea level, a ratio of arterial partial pressure of oxygen to fraction of inspired oxygen $\left(\mathrm{PaO}_{2} / \mathrm{FiO}_{2}\right)<300 \mathrm{mmHg}$ or lung infiltrates $>50 \%$.

\subsection{Critical illness}

Individuals whose symptoms rapidly deteriorate to respiratory failure and present septic shock, encephalopathy, myocardial injury or heart failure, coagulopathy and/or multiple organ dysfunction.

\section{What is the incubation period and the transmission of Covid-19? And, how is Covid-19 diagnosed?}

Many studies $[8,11,12]$ reported the mean incubation period of Covid-19 to be about 4-6 days with many weeks to die or recover. The study [13] estimated 14 days or more to develop symptoms. Interestingly, one study identified the four stages of evolution on chest CT scans among patients with Covid-19 from symptom onset; early-stage (0-4 days), progressive stage (5-8 days), peak stage (9-13 days) and absorption stage (more than 14 days) [12].

According to the potential transmission route of Covid-19, it started from SARS-like bat viruses as the primary reservoir and the consumption of those infected animals as food by humans was the beginning of the animal to human transmission. However, the intermediate source is still unknown [14]. Recently, the report confirmed the rapid transmission from human to human [15].

Covid-19 can spread through both direct and indirect contact. Direct contact is the source of Covid-19 transmission through touching mouth, nose or eyes with contaminated fingers. 
JHR

35,4

332

Indirect contact, such as contaminated objects, respiratory droplets and airborne contagion, is also another source of Covid-19 transmission.

For droplet transmission, viral particles (saliva or mucous droplets) in the droplets can spread during coughing, sneezing, laughing, singing, breathing and talking. Droplets typically cannot transverse more than $6 \mathrm{ft}$ or about $2 \mathrm{~m}$, and they cannot stay alive in the air for a long time [4]. Interestingly, the droplets remain on the surfaces of inanimate objects to produce a thin film of the virus. Depending on the types of the object surface, the virus resides on fomites in the environment for hours and days [16]. Half-lives of Covid-19 (hours) estimation in various surfaces and aerosol were (1) polypropylene (plastic) 15.9, (2) stainless steel 13.1, (3) cardboard 8.45, (4) copper 3.4 and (5) aerosol 2.74. The transmission of Covid-19 can occur from the contaminated surface to the hands of the people who touch the surface subsequently and then touches his or her own mucous membrane (mouth, nose or eyes).

For airborne transmission, Covid-19 can stay intact and contagious in droplets (less than 5 $\mu \mathrm{m}$ in diameter) and can survive in the air for up to $3 \mathrm{~h}$ [16]. This evidence indicated the viable and infectious form of Covid-19 involved airborne transmission. Also, two studies supported the assumption of airborne transmission through small particles with viral content might travel in indoor environments, covering distances up to $10 \mathrm{~m}$, starting from the emission sources $[17,18]$. Therefore, all of these conclusions about the airborne transmission of Covid19 in indoor environments, especially in crowded, poorly ventilated environments were in line with many previous studies [19-21].

Covid-19 infection is diagnosed by finding evidence of the virus from the respiratory tract system. There are three types of tests available for Covid-19 as follows [22, 23]:

(1) PCR test: This test looks for pieces of the virus that causes Covid-19 from the nose, throat or other possible areas in the respiratory tract to identify if the person has an active infection. This test provides the results for longer than the antigen test and antibody test. This test is typically highly accurate and usually does not need to be repeated.

(2) Antigen test: This test looks for pieces of proteins that make up the virus that causes Covid-19 to detect if the person has an active infection. Samples will be collected from a nasal or throat swab. This test provides results faster than the PCR test. Positive results from the antigen test are usually highly accurate, but negative results may need to be confirmed with a PCR test.

(3) Antibody (serology) test: This test looks for antibodies against the virus that causes Covid-19 in the blood to determine if there was a past infection, but it should not be used to diagnose an active infection. Samples will be collected from blood, and the test provides quick results. This test detects the antibodies and not the virus, so it might take several days or weeks for the body to develop enough antibodies to be detected.

\section{What is the current situation of Covid-19?}

According to a WHO report [5], as of August 25, 2020, the overall Covid-19 confirmed cases reached 23,518,343 along with 810,492 confirmed deaths in 216 different countries across the globe. Currently (August 25, 2020), the top five highest rankings of Covid-19 cases by regions are Americans 12,519,981 cases, Europe 4,016,133 cases, South-East Asia 3,666,425 cases, Eastern Mediterranean 1,840,077 cases, Africa 1,013,995 cases and Western Pacific 460,991 cases. Meanwhile, the top five highest rankings of Covid-19 cases by country are the USA $5,649,928$ cases, Brazil 3,605,783 cases, India 3,167,323 cases, Russia 966,189 cases and South Africa 611,450 cases. 
6. Is it true that Covid-9 is likely to attack old people?

Covid-19 is more likely to attack older men or women with comorbidities and can even cause death for those with severe respiratory diseases [8]. Based on the mechanism of action of Covid-19, the studies reported that the angiotensin-converting enzyme 2 (ACE2) has been identified as the cellular receptor for Covid-19. ACE2 is normally expressed on type I and type II alveolar epithelial cells of human epithelia of the lung and small intestine. The binding of Covid-19 to ACE2 results in an additional expression of ACE2, which can cause alveolar cell damage. It has also been found that the receptor binding ability of Covid-19 is 10 to 20 times stronger than that of SARS-CoV [24].

However, younger people with obesity can shift to severe Covid-19 disease. As obesity will interfere with respiratory function and restrict ventilation by obstructing diaphragm excursion, it impairs immune responses to viral infection, is pro-inflammatory and induces diabetes and oxidant stress to adversely affect the cardiovascular system [25]. Based on one study [26], it is reported that Covid-19 in the child population usually causes mild symptoms with fever or no fever, cough, fatigue, diarrhea, vomiting or abdominal distension. However, Covid-19 in children has a good prognosis, and most cases recovered after those mild symptoms. It can be explained by (1) the distribution of ACE2 receptors (lower binding capacity) in children's lung tissues is different from adult lung tissues [26, 27]; (2) children experienced exposure to other respiratory viruses such as respiratory syncytial virus, Influenza A, and Influenza B viruses, which potentially induce their serum antibody levels and could provide cross-protection [28]; (3) children's immune system is not fully mature, so the immune system of children does not respond in the same way as an adult's response [28].

\section{Is the alcohol-based hand rub solution efficient enough to prevent Covid-19 from spreading?}

The WHO and Centers for Disease Control and Prevention (CDC) suggested the prevention of Covid-19 by using soap with water for at least $20 \mathrm{~s}$, or ethanol alcohol with at least $60 \%$ alcohol, especially after being in a public area or after coughing and sneezing [29, 30]. One study [31] experimented with WHO's two alcohol-based formulations for hand sanitization from "Guidelines on Hand Hygiene in Health Care" to reduce pathogen infection and spreading. Formulation I was $85 \%$ ethanol (v/v), $0.725 \%$ glycerol $(\mathrm{v} / \mathrm{v})$ and $0.125 \%$ hydrogen peroxide (v/v). Formulation II was $75 \%$ isopropanol (w/w), $0.725 \%$ glycerol $(\mathrm{v} / \mathrm{v})$ and $0.125 \%$ hydrogen peroxide $(\mathrm{v} / \mathrm{v})$. The study also tested the effect of ethanol and isopropanol on Covid-19.

The study [31] reported that both WHO formulations can be effective for de-activating Covid-19 and recommended it to be used in health-care systems and in a viral outbreak situation. Also, both tested alcohols, ethanol and isopropanol, with a minimal final concentration of at least $30 \%$ can de-activate the virus in $30 \mathrm{~s}$. Therefore, alcohol-based hand rub products used in health care with at least a minimum alcohol concentration of $30 \%$ is powerful enough to get rid of Covid-19. However, frequent hand wash over all surfaces of hands with water and soap or alcohol is still required.

\section{What are the recommendations for Covid-19 prevention?}

According to the WHO, CDC, Ministry of Public Health (MOPH) in Thailand and other outbreak countries and research studies related to Covid-19 prevention [15, 30, 32-36], we summarized three simple methods for Covid-19 prevention as follows:

(1) "Physical distancing": Maintaining physical distancing of $1 \mathrm{~m}(3 \mathrm{ft})$ or more between yourself and others lowers the risk of infection, and a distance of $2 \mathrm{~m}(6 \mathrm{ft})$ could be more effective. The risk of Covid-19 infection is highly associated with the distance to 
JHR

35,4

334 the individual infected. If you stay too close to infected patients, you have a chance of breathing in the droplets, including the Covid-19 virus to the lungs. Another suggestion is to avoid traveling to crowded places because it is difficult to keep a physical distance.

"Face masks and eye protection": The use of face masks such as N95 respirators, surgical masks and eye protection has provided protection for health-care staff and people in the community. For health-care staff and administrators, N95 respirators offer more protection from Covid-19 transmission than surgical masks. Non-medical or clothing masks are essential to prevent contaminating infected people when they sneeze or cough. Non-medical masks might be made of different combinations of fabrics and materials, multi-layering sequences so the selection of clothing masks is very important. Moreover, the use of clothing masks also prevents the unnecessary use and shortage of surgical masks and N95 respirators, which are crucial for health-care workers in hospital settings.

At present, everybody should wear face coverings in public to prevent the spread of Covid-19 because asymptomatic Covid-19 patients can still spread the virus.

(2) "Hand washing": Hand hygiene practice is recommended for all health-care workers and general people of all ages. Regular and thorough use of soap with water for washing at least $20 \mathrm{~s}$, or alcohol-based hand rub, especially after having been in a public area and after coughing, or sneezing and before eating, touching eyes, nose and mouth is recommended. It is also important to avoid touching the facial T-zone (eyes, nose, and mouth) because this is the access point for the virus to get into the upper respiratory tract. Hands touch many surfaces, and the virus can pick up viruses by our hands. Once contaminated, the virus can enter the body through the mucous membrane on the eyes, nose and mouth [30, 33, 37].

\section{What is the treatment for Covid-19?}

Currently, there are not enough data to show whether some medications are safely and jointly administered with therapies for the treatment of Covid-19. However, some research studies already revealed the achievement of some promising results. The researcher summarized the possible agents against Covid-19 in Table 2.

\subsection{Covid-19 vaccination development}

As of July 29, 2020, the development of a vaccination for Covid-19 is still at the clinical trials stage. Based on the information of immune responses in preliminary studies, there are four promising candidates as below.

\subsection{Oxford/AstraZeneca UK [41]}

The name of the vaccine was $C h A d O x 1 n C o V-19$ (chimpanzee adenovirus-vectored vaccine), a non-replicating adenoviral vector displaying spike protein vaccine type. From April 23 to May 21, 2020, for Phase II clinical trial, 1,077 individuals aged 18-55 years old were registered in this single-blind, randomized controlled study in five sites in the UK. Participants were assigned to obtain either ChAdOx1 nCoV-19 $(n=543)$ or meningococcal conjugate vaccine (MenACWY) $(n=534)$. The results showed the vaccine was tolerated, safe and with a good T-cell response. The anti-spike IgG responses rose by day 28 with no severe side-effects. Fatigue and headache were the most common side-effects. The prophylactic use of paracetamol significantly reduced chills, muscle pain, headache and malaise in the first two days after vaccination. 


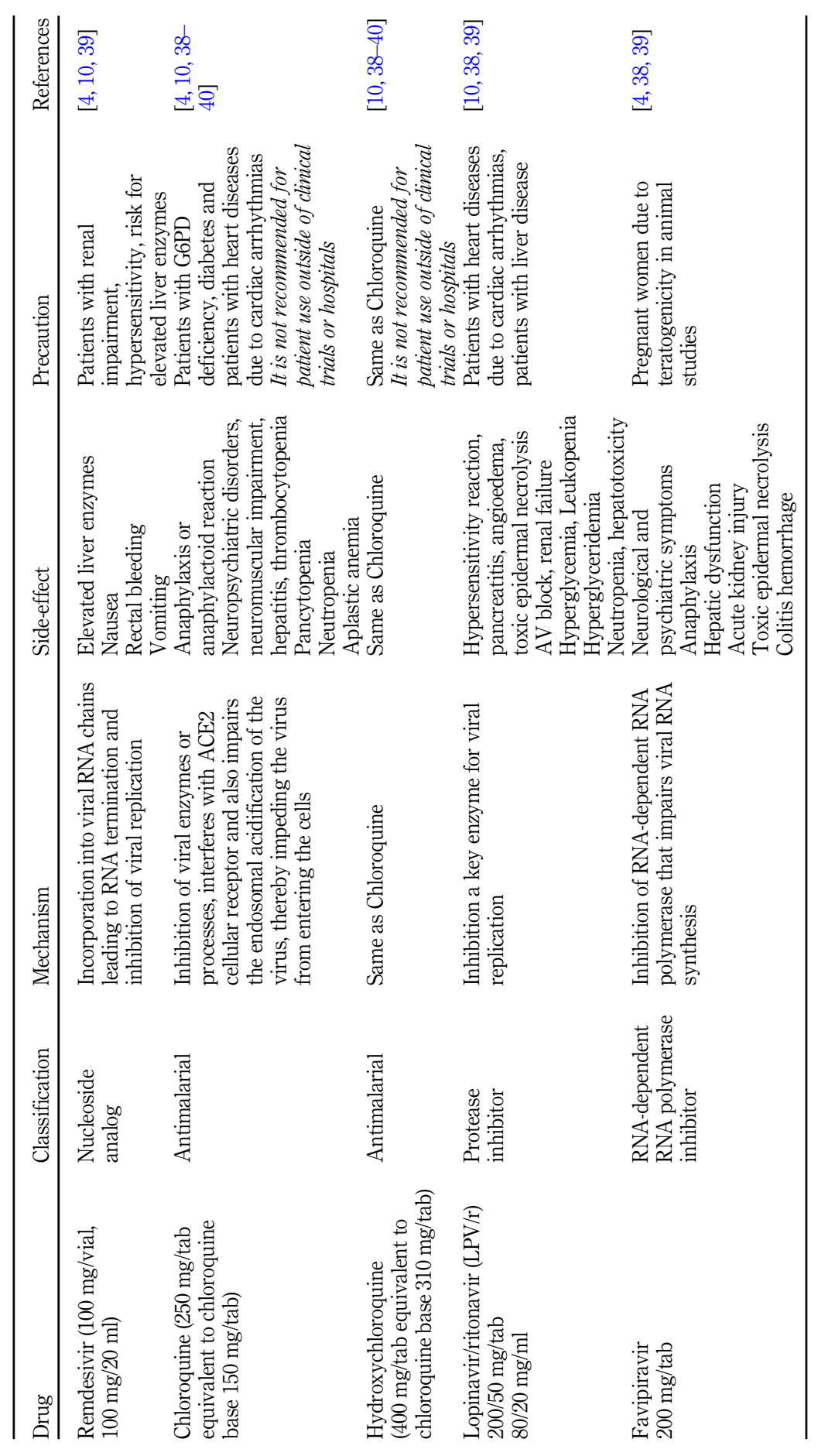

Covid-19

335

Table 2.

Potential antimicrobial drugs for the treatment of Covid-19 [4, 10 , 38-40] 
JHR

35,4

9.2 Moderna/NIAID, USA [42]

The name of the vaccine was $m R N A-1273$, a lip nanoparticle-encapsulated mRNA vaccine encoding pre-fusion stabilized from a viral spike (S) protein vaccine type. In the Phase I trial, 45 enrolled participants aged 18-55 years received doses of 25,100 , or $250 \mu \mathrm{g}$. The results of Phase I showed generally well-tolerated, neutralizing antibody titers at or above convalescent sera, no trial-limiting safety concerns, induction of Th1-biased CD4 T-cell responses in humans. The adverse events were fatigue, chills, headache, myalgia and pain at the injection site. Three participants $(21 \%)$ in the $250 \mu \mathrm{g}$ dose group reported one or more severe adverse events. In the Phase II trial, 600 healthy adults between the ages of 18-55 years and over 55 years were enrolled. Participants received a placebo, $50 \mu \mathrm{g}$ dose, or $100 \mu \mathrm{g}$ of both vaccinations and will be followed for one year (12 months). Moderna reported initial data from the Phase I trial of mRNA-1273 that the use of $25 \mu \mathrm{g}$ and $100 \mu \mathrm{g}$ dose levels showed dosedependent increases in immunogenicity, as well as between prime and boost.

\subsection{CanSino Biologics, China [41]}

CanSino's vaccine used the technology platform of a human adenovirus vector called $A d 5$ $n C O V$. In Phase I of the clinical trial, it was reported that the Ad5-nCOV vaccine was welltolerated and immunogenic, including inducing T-cell response by 14 days. The primary outcome was adverse reactions in the seven days post-vaccination. Currently, the Phase II clinical trial has enrolled 508 healthy subjects. During Phase II, it revealed that $95 \%$ of the candidates with the high dose and $91 \%$ of the candidates with low dose showed either cellular or humoral immune responses at day 28 after vaccination. Additionally, the results recommend a single-dose immunization schedule of Ad5-vectored Covid-19 vaccine at a low dose $\left(5 \times 10^{10}\right.$ viral particles) as a suitable regimen for healthy participants. The results from the Phase II study indicates that the Ad5-vectored Covid-19 vaccine has no serious adverse events, with only mild, transient adverse events. Currently, to evaluate the efficacy of the vaccine, the company has a plan for a randomized Phase III double-blinded placebocontrolled, international multicenter trial.

\subsection{Pfizer/BioNTech USA/Germany [43]}

Pfizer and BioNTech's vaccine used the technology of a lipid nanoparticle (LNP) formulated nucleoside-modified messenger RNA (mRNA) encoding the receptor-binding domain (RBD) of SARS-CoV-2 spike protein vaccine called BNT162b1. In Phase II, 60 subjects aged between 18 and 55 years were vaccinated between April 23, 2020, and May 22, 2020. With dose escalation (1 mcg, $10 \mathrm{mcg}, 30 \mathrm{mcg}, 50 \mathrm{mcg}, 60 \mathrm{mcg}$ ), each participant obtained two doses, with a first dose on day 1 and was boosted on day 22 . The results revealed that on day 28 or seven days after the second dose, all participants who received $30 \mathrm{mcg}$ of BNT162b1 had significantly elevated RBD-binding IgG antibodies, with geometric mean concentrations (GMCs) of 4,813 and 27, 872 units/mL, respectively. In conclusion, BNT162b1 induces functional and proinflammatory CD4 $+\mathrm{T}$ cell responses $(94.4 \%)$ and $\mathrm{CD} 8+\mathrm{T}$ cell responses $(80.6 \%)$ in almost all candidates, with Th1 polarization of the helper response with no serious adverse events. Local reactions at the injection site and systemic symptoms (mostly flu-like symptoms) were dose-dependent, which were generally mild to moderate.

\section{What is the situation of Covid-19 and lessons learned in Thailand?}

Following the Covid-19 pandemic that began in December 2019, the Thai government prepared five strategies: (1) a surveillance system; (2) case management, hospital infection and control; (3) laboratory testing; (4) preparation of health-care staff, health facilities and medical supplies; and (5) risk communication. On January 4, 2020, an Emergency Operation 
Center (EOC) was established as the center for Covid-19 management. EOC consists of several functions such as the establishment of a scientific knowledge response team, strategic response team, planning team, situation awareness team, operation team, risk communication team, law support and enforcement team, logistics and stockpiling team, point of entry team and liaison team [44].

At first, Thailand began screening passengers traveling from Wuhan by checking their temperatures at local and international airports. On January 13, 2020, the imported first case of Covid-19 was a 61-year-old Chinese woman from Wuhan City. Then, the first Thai citizen with Covid-19 and a travel history to Wuhan was found on January 23, 2020. As a result, Thailand strictly screened people who worked closely with or were in frequent contact with Chinese people such as tour guides, hotel staff, taxi drivers and airport staff. On January 31, 2020, the first identified Thai case human-to-human of Covid-19 was a taxi driver. On February 29, 2020, the MOPH announced Covid-19 as a dangerous communicable Disease Act, B.E. 2558 (A.D.2015) [44]. On March 26, 2020, the number of Covid-19 cases rose dramatically and exceeded more than 1,000 cases. On April 2, 2020, the Thai government announced a curfew between 10.00 p.m. to 4.00 a.m. throughout the Kingdom of Thailand. The Civil Aviation Authority of Thailand (CAAT) also announced that all international passenger flights were banned from entering Thailand [45]. From April 27 to August 2020, the number of new Covid-19 cases declined, with the most Covid-19 cases coming from outside Thailand with state quarantine, as shown in Figure 1. Meanwhile, the Thai government also gradually announced easing lockdown restrictions step by step. Today, Thailand has become one of the lowest-risk countries for Covid-19 and has been described as an example of a country that successfully fought against Covid-19's spread. However, there are challenges for Thailand after foreign tourists begin returning to Thailand. Two previous studies $[46,47]$ indicated that the movement between Thai people and foreign tourists along with generated income from tourist activities play an important role in the spread of Covid-19

New COVID-19 patients rate in Thailand
January 1st to August 25th, 2020

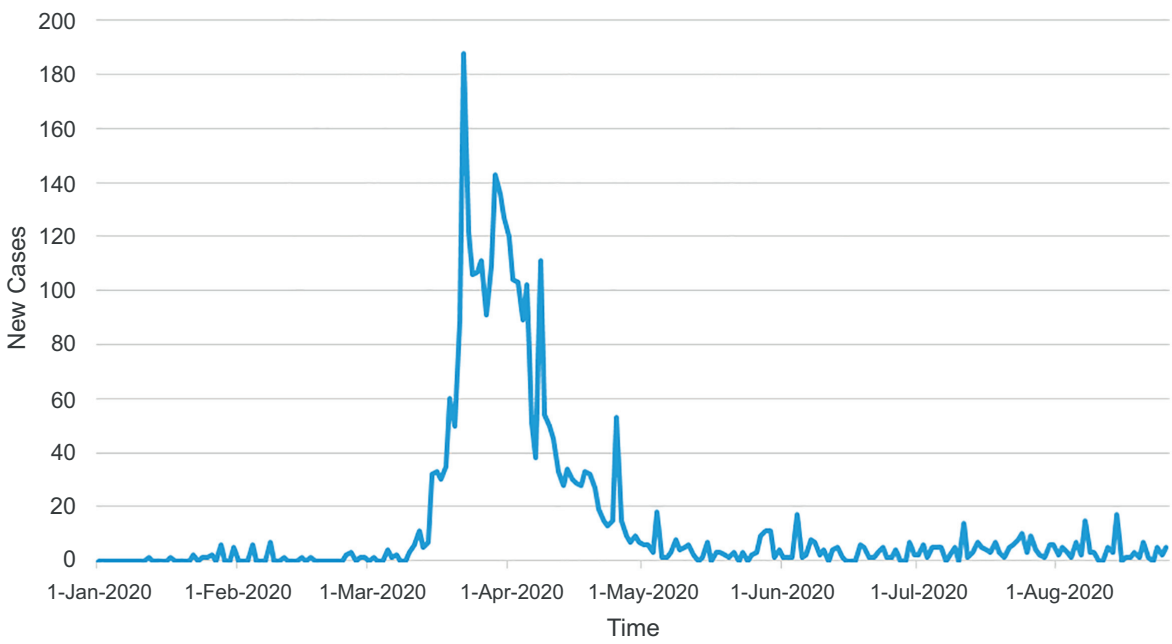

Note(s): Data from https://ddc.moph.go.th/viralpneumonia/eng/index.php
Figure 1.

New Covid-19 patient's rate in Thailand from January to August 2020 [48] 
JHR

35,4

\section{8}

in Thailand. This is in line with the information over the past few months (until August 2020) where new cases of Covid-19 were still found only in the state quarantines. As a result, all passengers who arrived from other countries had to be screened for Covid-19 and followed by 14 days in quarantine according to MOPH's regulations.

The possible reasons for the success of Thailand against the Covid-19 pandemic as follows.

(1) "Soft policy by government actions": Although the government announced the state of emergency and a curfew during the night (10.00 p.m.-4 a.m.), the essential health and living services such as hospitals, drug stores, supermarkets and takeout places were allowed to function. In Bangkok, public transportations such as buses, the light rail and the subway continued to operate. However, after the cases started declining along with continued careful monitoring, the Thai government also gradually relaxed the lockdown (from Phase 1 to Phase 5) through the announcement of the Center for Covid-19 Situation Administration (CCSA). The social distancing policy was also promoted during the easing of the lockdown relaxation. As a result, Thai people who suffered from the economic situation during Covid-19 could restore their businesses but had to strictly follow the Covid-19 prevention guidelines laid out by the government.

(2) "Village health volunteers (VHV)": VHV was the foundation of primary health care for the sustainability of the health-care system in Thailand. It was built under the concept of "community participation" related to public health promotion strategies and the selection of village health volunteers based on their willingness to do good deeds and have sufficient health-care knowledge. As a result, VHVs have a strong relationship and bond with health-care workers and some also have a close connection with community leaders [49, 50]. One VHV is responsible for 15 households, and thus, one province has approximately 20,000-30,000 VHVs. In short, there are approximately 80,000-100,000 VHVs across Thailand [50]. Currently, Thailand has approximately 1.4 million public health volunteers working alongside the health-promoting hospitals. Since the establishment of the VHV initiative 40 years ago in 1977, there are now VHVs in almost every village. These volunteers performed many tasks such as health survey, data collection and disease prevention campaigns. During the Covid-19 pandemic, health volunteers have cooperated with the Thai government policy and worked hard to prevent the spread of Covid-19. They also take care of a community member's health and improve their daily hygiene. The MOPH also provided guidelines for volunteers on how to protect themselves against Covid-19 and taught them how to make their own protective masks and hand sanitizers. Following these guidelines, health volunteers can pass on this knowledge to their families and community members. The VHVs work efficiently, knocking from door to door on at least 12 million doors to identify those at risk of contracting Covid-19 [51].

(3) "Integration of technology in health-care system" This is a collaboration between public and private sectors for controlling the spread of Covid-19 in Thailand. Regarding the VHVs, the deputy minister of Public Health signed a memorandum of understanding (MOU) between the Health Service Support Department and Advance Info Service (AIS) to provide health news for VHVs via a mobile application called "Aor Sor Mor Online" [52, 53]. The application was introduced in 2015. In the beginning, public health staff and health volunteers were the main users because both groups worked closely together for the sustainability of health-care systems in Thailand. This application can serve many functions such as reporting infectious disease cases and volunteer works, getting news, messaging and making 
appointments. Additionally, users can share useful information represented in the form of texts, images, audio, video and locations, as shown in Figure 2.

During the Covid-19 pandemic, VHVs use Aor Sor Mor Online to update the situation in their responsible areas, record the data from people who came back from risky countries, educate the community and follow-up on quarantine. This application also supports the readiness for the tasks of VHVs for lists of Covid-19 risky counties based on the database of the department of disease control, MOPH, knowledge about Covid-19, prevention and surveillance mechanism in the responsible area. Meanwhile, VHVs work with community leaders, networks, officers to prepare the readiness to fight against Covid-19 along with self-screening or self-checkup before going on the field to visit community or households equipped with facial masks, thermometers, alcohol gel, stickers for households that are being screened and educational materials about Covid-19 for public and equipment bags.

Another application for Covid-19 called "Thai Chana Application" is shown in Figure 3 along with 24 call centers at 1119: On May 15, 2020, the Thai Chana application, developed by the Ministry of Digital Economy and Society, was implemented for contact tracing and informing the public of risks. As of May 17, 2020, 2,002,897 million people used the Thai Chana platform with individuals scanning $\mathrm{QR}$ codes when entering the outlets 2.66 million check-ins at registered shops, and 1.85 million check-outs. The results showed good cooperation from business establishments and the public. The CCSA encouraged the public to use and download the "Thai Chana" application. The CCSA reiterated that data and information from this platform would be used by the Department of Disease Control and MOPH for a limited period and for contact tracing and treatment only [54].

(4) "Fact-based communications and centralized structure by the prime minister": Although Thailand set up the EOC on January 4, 2020, the agencies within the EOC still lack coordination. As a result, on March 27, 2020, the Thai government announced the establishment of a CCSA led by the prime minister, which centralized

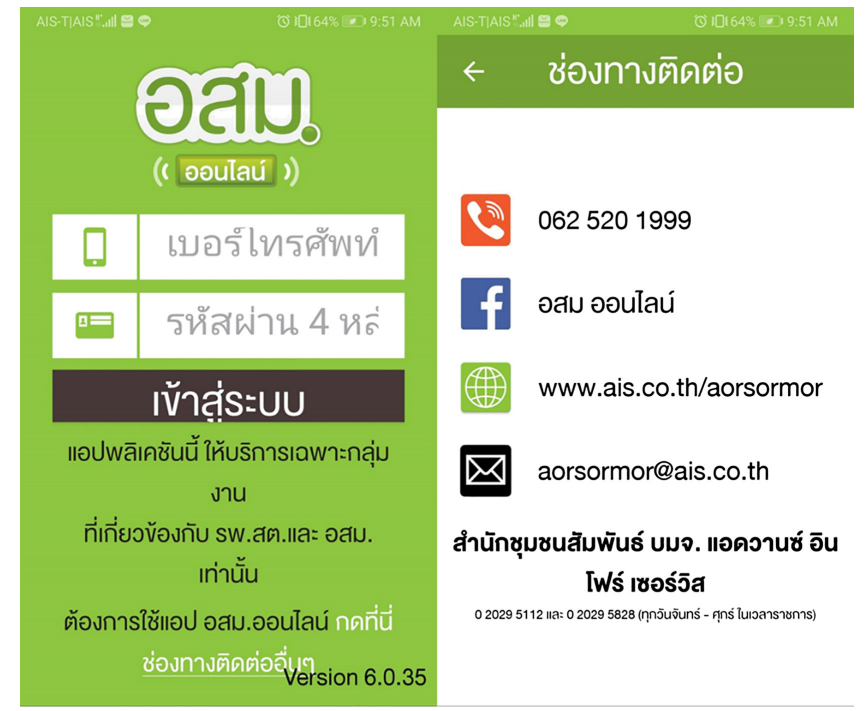

Note(s): Available for more information at https://www.ais.co.th/aorsormor/en//

Figure 2.

A screenshot of Aor Sor Mor Online on mobile application 
JHR
35,4

\section{0}

\section{Figure 3.}

A screenshot of Thai Chana application and its functions on mobile application

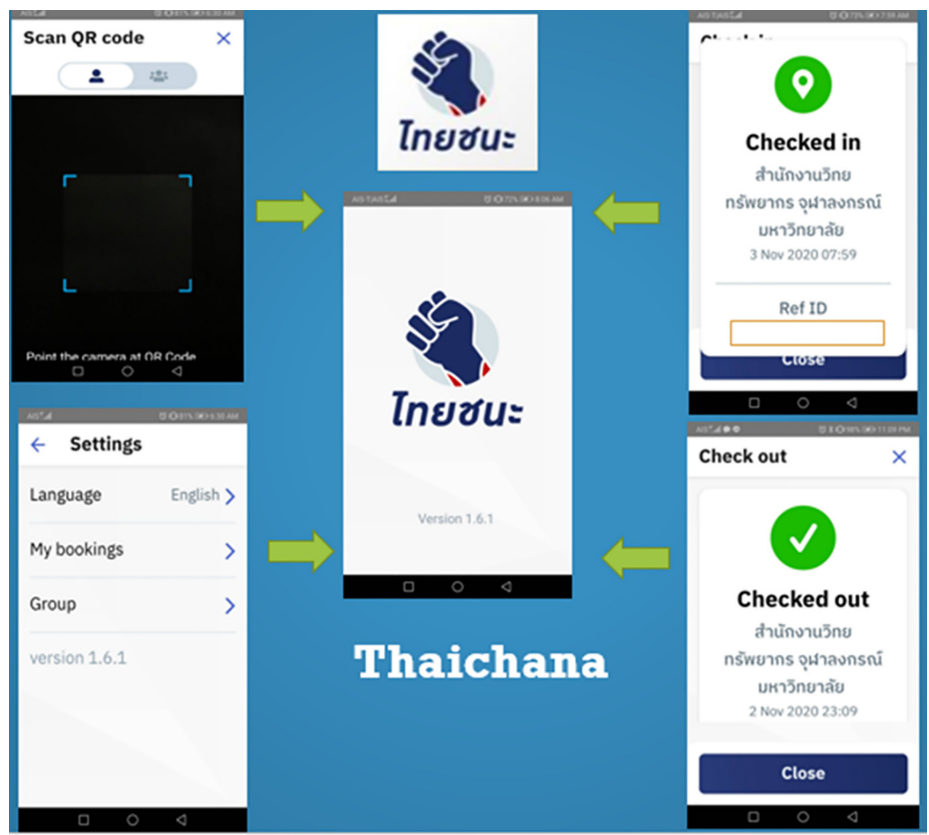

Note(s): Available for more information at https://www.ไทยชนะ.com

the structure of the organization appropriate for the performance and tasks. As a result, the enforcement and implementation from both central and local government regulation move forward in the same direction. Meanwhile, in the current Covid-19 situation, there is a lot of fake news and incorrect information that causes confusion, fear and distrust among the public. As a result, the CCSA appointed spokespersons with a medical background to provide updates on the Covid-19 situation and create awareness of Covid-19 prevention. If managed with sincerity, good manners, and focus on effective communication, it can generate public trust in the spokespersons' daily briefings and also in the Thai government's efforts as well.

\section{Conclusion}

The profiles of Covid-19 are dynamic and rapidly evolving. Some information is still under investigation. The study has limitations in terms of comparison of Thailand and other countries that have different health-care systems and infrastructures. This would have more explanations in terms of surveillance and prevention for Covid-19. However, the current study shares basic understandings of Covid-19 and the strategic actions from Thailand to fight against Covid-19, which can be adapted according to the different capacities and situations in other countries.

\section{References}

1. Zhu N, Zhang D, Wang W, Li X, Yang B, Song J, et al. A novel coronavirus from patients with pneumonia in China, 2019. N Engl J Med. 2020; 382(8): 727-33. doi: 10.1056/NEJMoa2001017. 
2. Tang X, Wu C, Li X, Song Y, Yao X, Wu X, et al. On the origin and continuing evolution of SARSCoV-2. Natl Sci Rev. 2020; 7(6): 1012-23. doi: 10.1093/nsr/nwaa036.

3. Xu XW, Wu XX, Jiang XG, Xu KJ, Ying LJ, Ma CL, et al. Clinical findings in a group of patients infected with the 2019 novel coronavirus (SARS-Cov-2) outside of Wuhan, China: retrospective case series. BMJ. 2020; 368: m606. doi: 10.1136/bmj.m606.

4. Rafiq D, Batool A, Bazaz MA. Three months of COVID-19: a systematic review and meta-analysis. Rev Med Virol. 2020; 30(4): e2113. doi: 10.1002/rmv.2113.

5. World Health Organization [WHO]. WHO coronavirus disease (Covid-19) dashboard. [cited 2020 August 14]. Available from: https://covid19.who.int/.

6. Wang D, Hu B, Hu C, Zhu F, Liu X, Zhang J, et al. Clinical characteristics of 138 hospitalized patients with 2019 novel coronavirus-infected pneumonia in Wuhan, China. JAMA. 2020; 323(11): 1061-9. doi: 10.1001/jama.2020.1585.

7. Huang C, Wang Y, Li X, Ren L, Zhao J, Hu Y, et al. Clinical features of patients infected with 2019 novel coronavirus in Wuhan, China. Lancet. 2020; 395(10223): 497-506. doi: 10.1016/S0140-6736(20) 30183-5.

8. Chen N, Zhou M, Dong X, Qu J, Gong F, Han Y, et al. Epidemiological and clinical characteristics of 99 cases of 2019 novel coronavirus pneumonia in Wuhan, China: a descriptive study. Lancet. 2020; 395(10223): 507-13. doi: 10.1016/S0140-6736(20)30211-7.

9. Clark A, Jit M, Warren-Gash C, Guthrie B, Wang HHX, Mercer SW, et al. Global, regional, and national estimates of the population at increased risk of severe COVID-19 due to underlying health conditions in 2020: a modelling study. Lancet Global Health. 2020; 8(8): 1003-17. doi: 10. 1016/S2214-109x(20)30264-3.

10. National Institute of Health [NIH]. Coronavirus disease 2019 (COVID-19) treatment guidelines. [cited 2020 June 26]. Available from: https://www.covid19treatmentguidelines.nih.gov/.

11. Backer JA, Klinkenberg D, Wallinga J. Incubation period of 2019 novel coronavirus (2019-nCoV) infections among travellers from Wuhan, China, 20-28 January 2020. Euro Surveill. 2020; 25(5). doi: 10.2807/1560-7917.ES.2020.25.5.2000062.

12. Pan F, Ye T, Sun P, Gui S, Liang B, Li L, et al. Time course of lung changes at chest CT during recovery from coronavirus disease 2019 (COVID-19). Radiology. 2020; 295(3): 715-21. doi: 10.1148/ radiol.2020200370.

13. Bi Q, Wu Y, Mei S, Ye C, Zou X, Zhang Z, et al. Epidemiology and transmission of COVID-19 in Shenzhen China: analysis of 391 cases and 1,286 of their close contacts. medRxiv. 2020. doi: 10. 1101/2020.03.03.20028423.

14. Shereen MA, Khan S, Kazmi A, Bashir N, Siddique R. COVID-19 infection: origin, transmission, and characteristics of human coronaviruses. J Adv Res. 2020; 24: 91-8. doi: 10.1016/j.jare.2020. 03.005 .

15. Remuzzi A, Remuzzi G. COVID-19 and Italy: what next?. Lancet. 2020; 395(10231): 1225-8. doi: 10. 1016/s0140-6736(20)30627-9.

16. van Doremalen N, Bushmaker T, Morris DH, Holbrook MG, Gamble A, Williamson BN, et al. Aerosol and surface stability of SARS-CoV-2 as compared with SARS-CoV-1. N Engl J Med. 2020; 382(16): 1564-7. doi: 10.1056/NEJMc2004973.

17. Morawska L, Tang JW, Bahnfleth W, Bluyssen PM, Boerstra A, Buonanno G, et al. How can airborne transmission of COVID-19 indoors be minimised?. Environ Int. 2020; 142: 105832. doi: 10. 1016/j.envint.2020.105832.

18. Paules CI, Marston HD, Fauci AS. Coronavirus infections-more than just the common cold. JAMA. 2020; 323(8): 707-8. doi: 10.1001/jama.2020.0757.

19. Coleman KK, Nguyen TT, Yadana S, Hansen-Estruch C, Lindsley WG, Gray GC. Bioaerosol sampling for respiratory viruses in Singapore's mass rapid transit network. Sci Rep. 2018; 8(1): 17476. doi: 10.1038/s41598-018-35896-1. 
JHR

35,4

342

20. Knibbs LD, Morawska L, Bell SC. The risk of airborne influenza transmission in passenger cars. Epidemiol Infect. 2012; 140(3): 474-8. doi: 10.1017/S0950268811000835.

21. Nishiura H, Oshitani H, Kobayashi T, Saito T, Sunagawa T, Matsui T, et al. Closed environments facilitate secondary transmission of coronavirus disease 2019 (COVID-19). medRxiv. 2020. doi: 10. 1101/2020.02.28.20029272.

22. US Food and Drug Administration [FDA]. Coronavirus testing basics. [cited 2020 August 17].Available from: https://www.fda.gov/media/140161/download.

23. Texas Health and Human Service. COVID-19 testing: pcr, antigen, and antibody tests explained. [cited 2020 August 17]. Available from: https://www.dshs.state.tx.us/coronavirus/docs/COVID19PCRvsSerologyTesting.pdf.

24. Wrapp D, Wang N, Corbett KS, Goldsmith JA, Hsieh CL, Abiona O, et al. Cryo-EM structure of the 2019-nCoV spike in the prefusion conformation. Science. 2020; 367(6483): 1260-3. doi: 10.1126/ science.abb2507.

25. Kass DA, Duggal P, Cingolani O. Obesity could shift severe COVID-19 disease to younger ages. Lancet. 2020; 395(10236): 1544-5. doi: 10.1016/S0140-6736(20)31024-2.

26. Mustafa NM, Selim LA. Characterisation of COVID-19 pandemic in paediatric age group: a systematic review and meta-analysis. J Clin Virol. 2020; 128: 104395. doi: 10.1016/j.jcv.2020. 104395.

27. Hoffmann M, Kleine-Weber H, Schroeder S, Kruger N, Herrler T, Erichsen S, et al. SARS-CoV-2 cell entry depends on ACE2 and TMPRSS2 and is blocked by a clinically proven protease inhibitor. Cell. 2020; 181(2): 271-80: e8. doi: 10.1016/j.cell.2020.02.052.

28. Dong Y, Mo X, Hu Y, Qi X, Jiang F, Jiang Z, et al. Epidemiology of COVID-19 among children in China. Pediatrics. 2020; 145(6): e20200702. doi: 10.1542/peds.2020-0702.

29. World Health Organization [WHO]. Getting your workplace ready for COVID-19. [updated 2020 March 19; cited 2020 June 4]. Available from: https:/apps.who.int/iris/bitstream/handle/10665/ 331584/WHO-2019-nCov-workplace-2020.2-eng.pdf?sequence $=1$ \&isAllowed $=y$.

30. Centers for Disease Control and Prevention [CDC]. How to protect yourself and others. [cited 2020 June 4]. Available from: https://www.cdc.gov/coronavirus/2019-ncov/prevent-getting-sick/ prevention.html.

31. Kratzel A, Todt D, V'kovski P, Steiner S, Gultom M, Thao TTN, et al. Inactivation of severe acute respiratory syndrome coronavirus 2 by WHO-recommended hand rub formulations and alcohols. Emerg. Infect. Dis. 2020; 26(7): 1592-5. doi: 10.3201/eid2607.200915.

32. Chu DK, Akl EA, Duda S, Solo K, Yaacoub S, Schunemann HJ, et al. Physical distancing, face masks, and eye protection to prevent person-to-person transmission of SARS-CoV-2 and COVID19: a systematic review and meta-analysis. Lancet. 2020; 395(10242): 1973-87. doi: 10.1016/S01406736(20)31142-9.

33. World Health Orgznization [WHO]. Coronavirus disease (COVID-19) advice for the public. [cited 2020 July 9]. Available from: https://www.who.int/emergencies/diseases/novel-coronavirus-2019/ advice-for-public.

34. Chen S, Yang J, Yang W, Wang C, Barnighausen T. COVID-19 control in China during mass population movements at New Year. Lancet. 2020; 395(10226): 764-6. doi: 10.1016/S0140-6736(20) 30421-9.

35. World Health Organization [WHO]. Advice on the use of masks in the context of COVID-19: interim guidance 5 June 2020. [cited 2020 July 6]. Available from: https:/www.who.int/ emergencies/diseases/novel-coronavirus-2019/advice-for-public/when-and-how-to-use-masks.

36. Covello V, Hyer R. COVID-19: simple answers to top questions, risk communication guide. [cited 2020 June 8]. Available from: https://www.astho.org/COVID-19/Q-and-A/.

37. Kakodkar P, Kaka N, Baig MN. A comprehensive literature review on the clinical presentation, and management of the pandemic coronavirus disease 2019 (COVID-19). Cureus. 2020; 12(4): e7560. doi: 10.7759/cureus.7560. 
38. Ministry of Public Health, Department of Disease Control. Guidelines for clinical practice, diagnosis, treatment and prevention of healthcare-associated infection in response to patients with COVID-19 infection. [updated 2020 April 8; cited 2020 August 14]. Available from: https:// ddc.moph.go.th/viralpneumonia/eng/file/guidelines/g_CPG.pdf.

39. Smith T, Bushek J, LeClaire A, Prosser T. COVID-19 drug therapy. [updated 2020 October 23; cited 2020 November 3]. Available from: https:/www.elsevier.com/_data/assets/pdf_file/0007/ 988648/COVID-19-Drug-Therapy_2020-8-28.pdf.

40. Cavalcanti AB, Zampieri FG, Rosa RG, Azevedo LCP, Veiga VC, Avezum A, et al. Hydroxychloroquine with or without Azithromycin in mild-to-moderate Covid-19. N Engl J Med. 2020; 383(21): 2041-52. doi: 10.1056/NEJMoa2019014.

41. Folegatti PM, Ewer KJ, Aley PK, Angus B, Becker S, Belij-Rammerstorfer S, et al. Safety and immunogenicity of the ChAdOx1 nCoV-19 vaccine against SARS-CoV-2: a preliminary report of a phase 1/2, single-blind, randomised controlled trial. Lancet. 2020; 396(10249): 467-78. doi: 10.1016/ S0140-6736(20)31604-4.

42. Jackson LA, Anderson EJ, Rouphael NG, Roberts PC, Makhene M, Coler RN, et al. An mRNA vaccine against SARS-CoV-2 - preliminary report. N Engl J Med. 2020; 383(20): 1920-31. doi: 10. 1056/NEJMoa2022483.

43. Sahin U, Muik A, Derhovanessian E, Vogler I, Kranz LM, Vormehr M, et al. Concurrent human antibody and $\mathrm{T}_{\mathrm{H}} 1$ type $\mathrm{T}$-cell responses elicited by a COVID-19 RNA vaccine. medRxiv. 2020. doi: 10.1101/2020.07.17.20140533.

44. Namwat C, Suphanchaimat R, Nittayasoot N, Iamsirithaworn S. Thailand's response against coronavirus disease 2019: challenges and lessons learned. Outbreak, Surveillance, Investigation and Response. 2020; 13(1): 33-7.

45. Royal Thai Embassy, Washington D.C. COVID-19 situation in Thailand. [cited 2020 June 15]. Available from: https://thaiembdc.org/covid-19inthailand/.

46. Tantrakarnapa K, Bhopdhornangkul B. Challenging the spread of COVID-19 in Thailand. One Health. 2020; 11: 100173. doi: 10.1016/j.onehlt.2020.100173.

47. Tantrakarnapa K, Bhopdhornangkul B, Nakhaapakorn K. Influencing factors of COVID-19 spreading: a case study of Thailand. Z Gesundh Wiss. 2020: 1-7. doi: 10.1007/s10389-02001329-5.

48. Ministry of Public Health, Department of Disease Control. Covid-19 infected situation report. [cited 2020 June 15]. Available from: https://covid19.ddc.moph.go.th/en.

49. Chuengsatiansup K, Suksuth P. Health volunteers in the context of change: potential and developmental strategies. Journal of Health Systems Research. 2007; 1(3-4): 268-79.

50. Jewjinda C, Chalermnirundorn N. The development of village health volunteers (VHVs) model with a participatory process. Proceedings of the 3rd RSU International Research Conference on Science and Technology, Social Science, and Humanities, 2018; 2018 May 4, Rangsit University. Pathum Thani. Rangsit University; 2018. p. 329-36.

51. The Nation Thailand. WHO lauds Thailand for good healthcare system. [updated 2020 April 14; cited 2020 June 30]. Available from: https://www.nationthailand.com/news/ 30385972 .

52. Khwanngern K, Natwichai J, Sitthikham S, Sitthikamtiub W, Kaveeta V, Rakchittapoke A, et al. Crowdsourcing platform for healthcare: cleft lip and cleft palate case studies. In: Barolli L, Nishino H, Enokido T and Takizawa M, (Eds) Advances in Intelligent Systems and Computing: the 22nd International Conference on Network-Based Information Systems, 2019 September 5-7, Oita, Japan. Cham. Springer; 2020. p. 465-74.

53. Barolli L, Nishino H, Enokido T, Takizawa M (Eds), Advances in networked-based information systems: the 22nd international conference on network-based information systems (NBiS-2019). Cham: Springer; 2019. 
JHR

35,4

344
54. Thailand, World Health Organization [WHO]. Coronavirus disease 2019 (COVID-19): WHO Thailand situation report. [updated 2020 May 27; cited 2020 July 4]. Available from: https://www. who.int/docs/default-source/searo/thailand/2020-05-27-tha-sitrep-86-covid19.pdf?sfvrsn= ffcb7080_2.

\section{Corresponding author}

Pramon Viwattanakulvanid can be contacted at: Pramon.V@chula.ac.th

For instructions on how to order reprints of this article, please visit our website: www.emeraldgrouppublishing.com/licensing/reprints.htm Or contact us for further details: permissions@emeraldinsight.com 